\title{
Pelatihan Pemanfaatan Digital Marketing Dalam Pengembangan Pemasaran dan Kewirausahaan UKM Pada Kota Sawahlunto
}

\author{
GeovanneFarell*1, ${ }^{*}$ Thamrin², Igor Novid ${ }^{3}$ \\ 123Teknik Elektronika/ Pendidikan Teknik Informatika/Universitas Negeri Padang \\ *)Corresponding author, ఏgeovannefarell@ft.unp.ac.id
}

Revisi 30/06/2019;

Diterima 20/07/2019;

Publish 08/08/2019
Kata kunci:UKM, pelatihanketerampilan, dan digital marketing.

\begin{abstract}
Abstrak
Digital marketing telah berkembang dengan sangat pesat seja penggunaan internet yang tinggi. Tingkat penggunaan ini dipicu dengan kehadiran smartphone dengan harga yang sangat terjangkau. Tetapi penggunaan digitial marketing tidak banyak disadari oleh pelaku bisnis, terutama para UKM di Kota Sawahlunto. Kebanyakan UKM di kota ii beranggapan bahwa digital marketing merupakan tempat untuk terjadinya transaksi, hal ini berbeda jauh dengan pengertian sebenarnya dari digitial marketing. Karena digital marketing ini merupakan pemanfaatan semua sumber daya yang berbeda pada internet sebagai tempat pemberi informasi sebagai produk-produk yang dimiliki oleh UKM tersebut.Media sosial yang digunakan untuk digital marketing tidak hanya tertumpu pada media sosial yang sengaja dibuat untuk UKM, juga media sosial yang dimiliki oleh pegawai atau karyawan dari UKM tersebut. Sehingga pemasaran produk memiliki jangkauan yang lebih luas, dan dengan demikian penjualan produk dari UKM yang berada pada kota Sawahlunto juga meningkat.
\end{abstract}

\section{PENDAHULUAN}

Analisis Situasi

Kota sawahlunto mempunyai UKM yang beragam, banyakolahan dan produk UKM tidak banyak dikenal oleh masyarakat luas, hal ini didasarkan pada data dinas perindustrian, perdagangan, koperasi dan UKM. Tingkat jangkauan pemasaran dinilai masih rendah, karena UKM hanya mengandalkan took dirumah, sementara dengan banyaknya layanan jual beli online membuat persaingan produk UKM kota sawahlunto banyak yang tidak terjangkau informasi oleh masyarakat. 
Suluah Bendang: Jurnal Ilmiah Pengabdian Kepada Masyarakat

Vol.19, No.1, 2019

Geovanne Farell, Thamrin,Igor Novid

Produk UKM kota sawahlunto memiliki kualitas yang cukup baik, hal ini dibuktikan dengan Sering di adakan festival internasional di kota sawahlunto, yang mendapatkan kesan baik dari masyarakat yang membeli saat acara berlangsung. Produk yang dihasilkan oleh UKM kota Sawahlunto masih banyak yang belum bias dibeli atau didapatkan informasinya oleh masyarakat luas, Karena produk-produk yang dihasilkan masih banyak informasinya disediakan secara offline. Hal lain yang dapat mempengaruhi tingkat daya jual UKM adalah sedikitnya pelaku UKM yang paham terhadap foto produk.

Berdasarkan uraian di atas, tim pengabdian tertarik untuk melaksanakan pengabdian di kota sawahlunto untuk melaksanakan pelatihan Digital Marketing dengan menggunakan aplikasi Google Business denganjudul“Pelatihan Pemanfaatan Digital Marketing Dalam Pengembangan Pemasaran Dan Kewirausahaan UKM Pada Kota Sawahlunto”.

\section{Solusi dan Target Luaran}

Solusi untuk menangani permasalahan yang terjadi adalah dengan digital marketing produk menjadi layak jual dan promosi.Melalui foto produk yang komersial, akan meningkatkan nilai jual produk yang tinggi dari harga kisaran sebelum di kemas denganr api.

Solusi yang ditawarkan untuk masalah keduaa dalah meningkatkan promosi, dibuat sebuah merk digital melalui internet. Dengan fakta bahwa pengguna internet di Indonesia cukup banyak, maka internet brand akan meningkatkan promosi di masyarakat.

Promosi yang bagus dapat dilakukan dengan melakukan riset dan analisis terhadap pasar. Saat ini merupakan era dimana Internet menjadi salah satu bagian yang tidak dapat dipisahkan dari kehidupan bermasyarakat. Kelengkapan dan kejelasan informasi menjadi salah satu factor pemicu kepercayaan masyarakat terhadap suatu lembaga. Promosi yang selama ini telah dilakukanya kini memasarkan produk melalui pameran-pameran dan melalui media social facebook yang dimiliki oleh pemilik usaha dagang, sehingga tingkat pengenalan produk masih rendah karena jangkauan area promosinya juga pendek. Dengan menerapkan internet brand, diharapkan tingkat pengetahuan akan produk inovasi, promosi dan penjualan produk akan meningkat.

Jenis luaran yang dihasilkan pada program pengabdian masyarakat iniadalah sebuah publikasi jurnal nasional dan teknologi tepatguna yang berupa web google bisnis untuk mempromosikanprodukyang telah dimiliki oleh mitra.

\section{METODE PELAKSANAAN}

Metode kegiatan ini berupa pelatihan kepada pelaku UKM Kota Sawahlunto. Setelah diberi pelatihan, selanjutnya mereka dibimbing untuk menerapkan hasil pelatihan dalam rangka memanfaatkan aplikasi Google Business dalam pemasaran.

Berikut ini adalah tahapan pelatihan yang dilakukan:

1. Tahap Persiapan, yang dilakukan meliputi :

a. Survei.

b. Pemantapan dan penentuan lokasi dan sasaran.

c. Penyusunan bahan/materi pelatihan, yang meliputi: makalah dan modul untuk kegiatan pelatihan. 
Suluah Bendang: Jurnal IImiah Pengabdian Kepada Masyarakat

Vol.19, No.1, 2019

Geovanne Farell, Thamrin,Igor Novid

2. Tahap Pelaksanaan Pelatihan

Tahap ini menjelaskan tentang pentingnya bagi pelaku usaha untuk mengetahui aplikasi Google Business dan mengaplikasikannya di dunia usaha. Selanjutnya, sesi pelatihan yang menitik beratkan pada kemampuan membuat bahan pemasaran dengan menggunakan aplikasi Google Business. Pemberian pelatihan ini dilakukan dengan teknik simulasi agar para pelaku usaha mendapatkan pengalaman langsung sekaligus pengayaan dari teman-temannya dan tim pelatih.

3. Metode Pelatihan

Untuk melaksanakan kegiatan tersebut digunakan beberapa metode pelatihan, yaitu:

a. Metode Ceramah

Metode ceramah dipilih untuk memberikan penjelasan bagi guru untuk mengetahui aplikasi Google Business dan mengaplikasikannya untuk pembelajaran di dunia usaha.

b. Metode Tanya Jawab

Metode tanya jawab sangat penting bagi para peserta pelatihan, baik di saat menerima penjelasan tentang topik yang dibahas serta saat mempraktekkannya

c. Metode Simulasi

Metode simulasi ini sangat penting diberikan kepada para peserta pelatihan untuk memberikan kesempatan mempraktekkan materi pelatihan yang diperoleh.

Evaluasi proses dan hasil (pencapaian tujuan pelatihan) dilakukan dengan angket tanya jawab, dan observasi. Sedangkan evaluasi aspek penyelenggaraan pelatihan dilakukan dengan pemberian angketindikator keberhasilan dalam pelaksanaan pelatihan media pembelajaran dengan menggunakan aplikasi Google Business untuk pelaku usaha ada 2 metode, yaitu:.

1. Evaluasi selama proses pelatihan

Evaluasi saat pelaksanaan pelatihan meliputi, keterlibatan dan kemampuan peserta setiap tahap pelatihan. Pada tahap akhir, peserta diharapkan dapat memanfaatkan aplikasi Google Business untuk membuat media pemasaran.

2. Evaluasi Pasca Pelatihan

Keberhasilan kegiatan pengabdian masyarakat ini akan dievaluasi berdasarkan taraf penyelesaian materi pelatihan, dan Tim Pengabdian akan melakukan evaluasi dengan mengamati dan memeriksa hasil desain pemanfaatan aplikasi Google Business dalam pembuatan media pemasaran.

\section{HASIL DAN LUARAN YANG DICAPAI}

Program Kegiatan Pengadian Kepada Masyarakat (PKM) dengan judul "Pelatihan Pemanfaatan Digital Marketing Dalam Pengembangan Pemasaran Dan Kewirausahaan UKM Pada Kota Sawahlunto" sudah dilaksanakan secara 100\%. Kegiatan inti yaitu pelatihan pengembangan pemasaran melalui digital yang telah dilaksanakan Juli 2019. Berikut adalah rincian kegiatan yang sudah dilakukan oleh tim pelaksanaan pengabdian kepada masyarakat di Kota Sawahlunto. 
Suluah Bendang: Jurnal IImiah Pengabdian Kepada Masyarakat

Vol.19, No.1, 2019

Geovanne Farell, Thamrin,Igor Novid

\section{Hasil Yang Dicapai}

\section{Persiapan Kegiatan PKM}

Pada tanggal 28 Juli 2019 dilakukan koordinasi dengan pihak UKM Kota Sawahlunto untuk memastikan kembali fasilitas yang dibutuhkan untuk pelaksanaan kegiatan seperti ruangan, computer, headset dan software pendukung lainnya. Selain fasilitas tim juga meminta informasi mengenai peserta pelatihan. informasi yang didapatkan dari hasil koordinasi adalah UKM kota Sawahlunto sudah menggunakan computer dan smartphone. Dari hasil wawancara juga diketahui bahwa sebagian besar UKM di Kota Sawahlunto sudah memiliki laptop dan LCD proyektor pun sudah disediakan sebagai fasilitas UKM. Pelaksanaan Kegiatan PKM (Pelatihan Pengembangan Pemasaran UKM Melalui Digital).

\section{PersiapanPelatihan}

Lokasi kegiatan pelatihan berjarak $130 \mathrm{~km}$ yang ditempuh dalam waktu 4 jam. Tim kegiatan pengabdian kepada masyarakat berangkat dari Padang pada hari Minggu tanggal 28 Juli 2019. Selain itu, tim pengabdian bersama pihak sekolah telah berkoordinasi untuk melakukan persiapan pelatihan meliputi penyiapan materi dan bahan pelatihan, seperti :Tempat dan ruangan pelatihan Konsumsi pelatihan Jadwal Pelatihan Pelatihan dilaksanakan di Kota Sawahlunto pada tanggal 28 Juli 2019 - 31 Juli 2019 pada hariMinggu - Rabu.KegiatanPelatihan Kegiatan pelatihan dilakukan sesuai jadwal yang telah disusun. Untukmengetahuiseberapabesarpemahaman dan pengetahuan UKM terhadappengembangan digital marketing maka terlebih dahulu dilakukan pre-test. Setelah pre-test dilakukan, materi - materi pelatihan diberikan selama 4 hari kegiatan pelatihan. Kegiatan pengabdian kepada masyarakat, mulai dari pembukaan sampai kegiatan pelatihan, dilakukan di Kota Sawahlunto. Berikut adalah beberapa bukti foto pelaksanaan kegiatan "Pelatihan Pengembangan Pemasaran Kewirausahaan Melalui Digital” bagi Kota Sawahlunto.

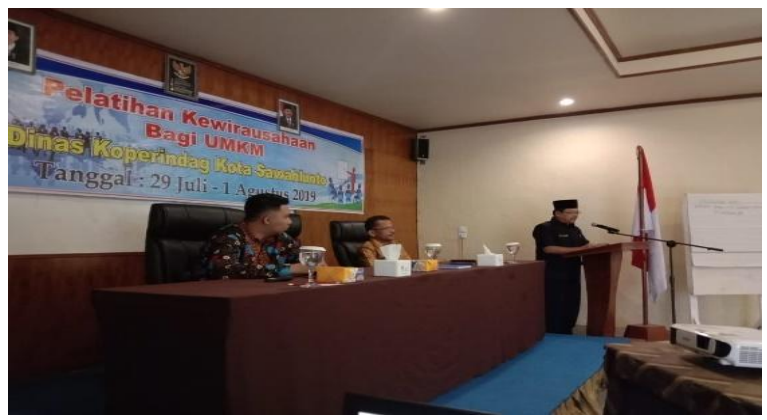

Gambar 1Sambutan dari kepala DISKOPERINDAGKOP 
Suluah Bendang: Jurnal Ilmiah Pengabdian Kepada Masyarakat Vol.19, No.1, 2019

Geovanne Farell, Thamrin, Igor Novid

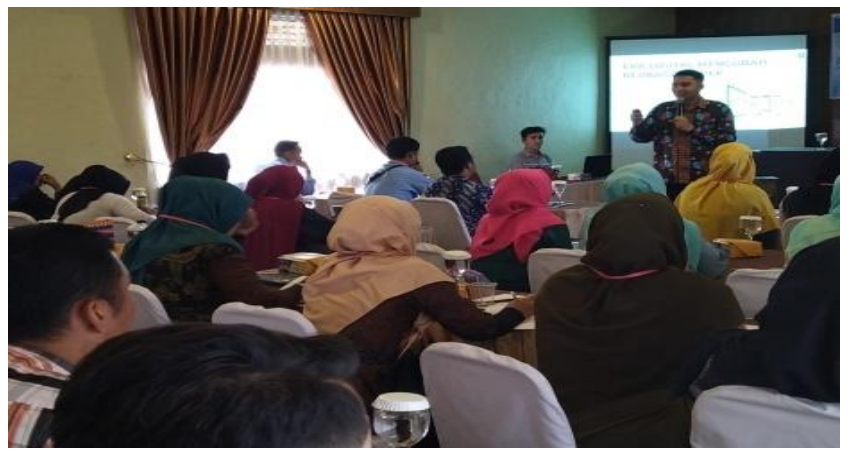

Gambar 2.Proses PemberianInformasi Pelatihan oleh Tim Pengabdian

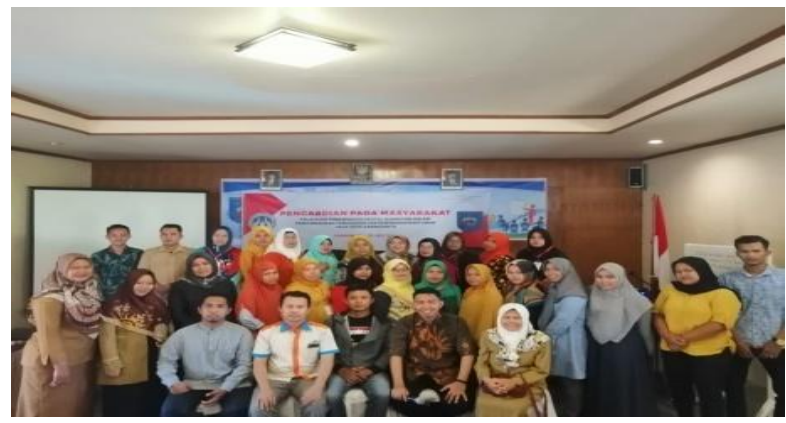

Gambar 3.Foto Bersama Peserta dan Tim Pengabdian

\section{KESIMPULAN}

Program Kemitraan Masyarakat dengan tema pelatihan pemanfaatan digital marketing dalam pengembangan pemasaran dan kewirausahaan ukm pada kota sawahlunto, yang telah diselenggarakan pada tanggal 28 s.d 31 Juli 2019 telah mampu mengasilkan keluaran PKM berupa 16 web google bisnis, peningkatan keterampilan peserta latih, dan publikasi di media social internet. Kegiatan PKM ini menumbuhkan ide-ide kreatif bagi peserta latih dalam mengasilkan cara pemasaran yang mempunyai daya saing global dan sebuah foto produk yang bernilai jual dengan memanfaatkan bahan yang ada disekitar lingkungan. 
Suluah Bendang: Jurnal IImiah Pengabdian Kepada Masyarakat

Vol.19, No.1, 2019

Geovanne Farell, Thamrin,Igor Novid

\section{DAFTAR PUSTAKA}

TechInAsia, 2014, [online] https://id.techinasia.com/statistik-pengguna-Internetdi-asia-danindonesia-slideshow[diakses pada tanggal 16 September 2017]

Puspitasari, L. \& Ishii, K., 2016, 'Digital divides and mobile Internet in Indonesia:Impact of smartphones', Journal of Telematics and Informatics, Volume 33, Issue 2, pp 472-483.

Ghezzia, Antonio., et all., 2016, 'A role for startups in unleashing the disruptivepower of social media', International Journal of Information Management,Volume 36, Issue 6, Part A, pp 1152-1159.

Tayebi, A., 2013, 'Planning activism: Using Social Media to claim marginalized citizens' right to the city', Cities Journal, Volume 32, pp 88-93.

Rowley, J., 2008, 'Understanding digital content marketing', Journal of Marketing Management, Volume 24, 2008 - Issue 5-6, pp. 517-540. 